\title{
THE VICTORIAN CREATION OF BUDDHISM
}

Philip C. Almond. The British Discovery of Buddhism. Cambridge: Cambridge University Press, 1988.

The history of the non-Buddhist world's encounter with that set of phenomena lumped together under the rubric of "Buddhism" is a long one, though one to which few reliable and readable guides exist. One of the best undoubtedly remains Henri de Lubac's La Rencontre $d u$ Bouddhisme et de l'Occident, ${ }^{1}$ which has the merit of considering both scholarly and popular "meetings." Philip Almond's new contribution is considerably more limited in scope than Lubac's; as its title suggests, it is basically a history documenting the British encounter with information and ideas about Buddhism in the Victorian period. This history is sketched through the collection and interpretation of an impressive amount of data from original documents of the period. Yet Almond's book also proposes (or, as I shall suggest, adopts from elsewhere) a thesis about intellectual colonialism and imperialism and the effects this has had on all thinking about Buddhism during and since Victorian times. The evidence collected and the observations offered by Almond strongly point to the need for some serious reevaluation of a number of ideas about Buddhism current today. These are ideas which, as Almond shows, we moderns have inherited from our predecessors without a sufficient awareness of the factors which motivated those ideas to begin with.

An examination of the presuppositions behind Almond's own work, however, reveals other equally deeply ingrained ideas, ideas which likewise underlie much of the reasoning and argumentation of contemporary discourses on Buddhism. A careful look at Almond's work, therefore, will provide us an opportunity to gaze both backwards at our heritage and inwards at our own preconceptions.

In contrast to what could be seen as something of a companion volume, The British Discovery of Hinduism in the Eighteenth Century, ${ }^{2}$ 
which contains mostly original materials with about fifty pages of interpretive preamble, Almond avoids lengthy quotations, preferring to sample a large number of different works, providing inter alia some analyses of the mass of data he has gathered together. The focus of his study is solidly on material that formed contemporary popular opinion, rather than on specialist discourse or works that might be identified as important milestones only in retrospect but which had little popular impact at the time.

The main thesis of Almond's work may be characterized as the idea that one can identify a two-fold position for Buddhism in Victorian England. On the one hand Buddhism was a tool used by various groups and individuals to promote certain social, political or religious agendas, with respect to both English domestic and foreign (or perhaps better colonial) policies. On the other hand, the corollary to this is that Buddhism itself was transformed or even "created" in the context of its utility vis-à-vis those agendas - it was brought into being in the Victorian world for the Victorian world. There was a marked tendency for these agendas to both overlap and be set off one against the other. An important factor which in part allowed this whole process was an at least implicit awareness among scholars and students of Buddhism of a gap between Buddhist literature and doctrine and contemporary Buddhist practice. This book, a treasuretrove of data and materials for the study of the Western reception of Buddhism, is full of insightful and fascinating observations. In particular, Almond's sensitivity to the ideological pressures which have helped shape the modern understanding of Buddhism, not only in the West but via the West in Asia as well, makes this book stimulating and important.

Almond has outlined the plan of his book succinctly, and a good place to begin may be with an examination of his own characterization of his venture (p. 4):

In the first place, I want to argue that there was an imaginative creation of Buddhism in the first half of the nineteenth century, and that the Western creation of Buddhism progressively enabled certain aspects of Eastern cultures to be defined, delimited, and classified. In the second place, I want to analyze the discourse about Buddhism that was created and sustained by the reification of the term 'Buddhism', and which, in its turn, defined the nature and content of this entity. I hope to show the way in which 
'Buddhism' was created, and discourse about it determined, by the Victorian culture in which it emerged as an object of discourse.

In so doing, something of the history of Buddhist studies in the West, and especially in Great Britain, will be thrown into relief. ... part of the purpose of this book is to demonstrate as precisely as possible the way in which the scholarly analysis of Buddhism was influenced by the object it created, and the discourse that defined that object. Buddhist scholarship was not only the cause but also the effect of that which it brought into being - Buddhism.

Almond seems to suggest not only that the way in which Europeans were able to talk about Buddhism, but the very existence of that "Buddhism" itself, were both products of the Victorian cultural background of those Europeans. Is it really so that Buddhist scholarship "brought [Buddhism] into being"? A few pages later, Almond again states his goals and, explicitly, his presuppositions (pages 5-6):

I am not concerned with the extent to which Victorian interpretations of Buddhism correctly or incorrectly perceived, selected, reflected on, and interpreted the congeries of texts, persons, events and phenomena in various cultures that it classified as Buddhist. My concern is rather with how these were presented by the West, in the West, and primarily for the West. . . Central to my argument, then, is the presupposition that the construction and interpretation of Buddhism reveals much about nineteenth-century concerns and can be read as an important sign of crucial sociocultural aspects of the Victorian period. ... Consequently, in the chapters which follow, discourse about Buddhism has been examined not only with a view to discerning the way in which the image of an alien religiosity was constructed, but also with the aim of demonstrating the way in which the discourse thus constructed illuminates the broad socio-cultural context in which it was created. Discourse about Buddhism provides ... a mirror in which was reflected an image not only of the Orient, but of the Victorian world also.

There is a subtle fallacy here that may reveal something of the theoretical underpinnings of Almond's discussions. Almond claims not to be interested in the relationship between the objective truth of Buddhism's existence and situation and the Victorian interpretation of that objective existence. He is interested in how the texts, persons and so forth in Buddhist cultures were presented, or in other words interpreted, in the West. Unless I have missed something, this does not make sense. If it is assumed that "the construction and interpretation of Buddhism reveals much about nineteenth-century concerns," then it is necessarily true that "Buddhism" exists outside of and independent of those nineteenth-century concerns, through the lens of which it is internreted There must he a Buddhism which some nennle 
and some works of scholarship are able to reflect more accurately, honestly and directly than are others. The final phrase quoted above repeats this idea: Looking at how people talked about Buddhism makes it possible for us to see in their discussions not only a reflection of the Orient, the home of Buddhism, but also a reflection of their contemporary world from the standpoint of which they observe that Buddhism. Here is the essentialist fallacy: How can we talk about how a person or group of persons interpreted a notion without any base line with which to compare that interpretation? The "how" of the phrase "how these were presented by the West ..." assumes some standard against which to judge, some if not objective then at least more objective standpoint. Almond's presentation of course must and does make just such assumptions, although he appears to want to deny this.

The first chapter of Almond's book, "The discovery of Buddhism," begins with an introductory sketch of Western contacts with Buddhist phenomena in "the Orient." Following this brief discussion Almond (p. 12) makes explicit what was implied in the passage quoted above:

Throughout the preceding discussion, I have tried carefully to avoid giving the impression that Buddhism existed prior to the end of the eighteenth century: that it was waiting in the wings, so to say, to be discovered; that it was floating in some aethereal Oriental limbo expecting its objective embodiment. On the contrary, what we are witnessing in the period from the later part of the eighteenth century to the beginning of the Victorian period in the latter half of the 1830 s is the creation of Buddhism. It becomes an object, is constituted as such; it takes form as an entity that 'exists' over against the various cultures which can now be perceived as instancing it, manifesting it, in an enormous variety of ways.

This formulation is essentially incompatible with the rest of Almond's argument. Perhaps it might be better to state it this way: Prior to the end of the eighteenth century, there was no Buddhism in the European imagination. For Europeans, Buddhism did not exist in the sense that the world they knew did not include among its many objects one called "Buddhism." But at a certain point the idea of such an object gradually "congealed," and became an object; "Buddhism" was created in and for the Western imagination. Historically speaking, of course, Buddhists in Asia, to the extent that they have been aware of the existence of others who share their faith but manifest it in a 
different fashion, have historically "created" Buddhism all along. In this sense, it is a question of identity. It may be possible from one point of view to refer to this as a difference between an internal creation and an external and adventitious one, an emic view and an etic one, to use modern jargon. This ambiguous ontological status of Buddhism was at least hinted at as early as 1909 by Louis de la Vallée Poussin, who in a discussion of the "many species of Buddhism" observed that "Buddhism, to speak as do the metaphysicians, does not exist 'in itself' and by itself." 3 To use a notion made explicit in Indian philosophy, but probably implicit in much Western thinking and perhaps in Almond's formulation of his problem, to exist in itself means to have a single, unchanging nature. If "Buddhism" existed, it could not be many things but only one, and it could not change through time or place. This idea lies at the root of the Buddhist philosophical rejection of "self," and at the root of our acceptance of the idea that Buddhism need not be "floating in some aethereal Oriental limbo" to nevertheless pre-exist its "creation" in a Western discourse. There need not be an ideal Buddhism (in a Platonic sense) for there to be some Buddhisms. It is possible to suggest that "a" Buddhism, or even better yet "Buddhisms," were created by Europeans and inevitably for Europeans in the eighteenth century, but this creation was hardly, as Almond sometimes seems to suggest, ex nihilo. One cannot proceed with the idea that it is possible to ignore the question of how far the Victorian interpreters correctly or incorrectly understood their object.

On the other hand, our very judgment of the accuracy of the Victorian interpreters of Buddhism immediately calls into question our own standpoint; how do we know when the Victorians presented a view more or less in concord with indigenous realities, in other words, a "correct understanding," and when they were responding more than anything else to their own historical situation? It is a fruitless excercise in conceit, however, to look down upon those comments of our predecessors with which we cannot agree as if we have necessarily attained some higher standpoint. If we want to understand how far our inherited ideas are justifiable in light of contemporary presumptions, it may be even more profitable, for example, to turn things around and examine those ideas inherited from former ages with which we do 
agree, and to try to see if we can actually follow the reasoning which led to the acceptance of these opinions. We will no doubt be surprised at the amount of revision in our own opinions we find this examination to necessitate. ${ }^{4}$

Almond's suggestion of the importance of the Victorian world's role in the "creation" of Buddhism is based on his thesis about ideological imperialism. The evidence for this thesis comes from an examination of the discourse within which that creative process was expressed. If "Buddhism" is something created by those who think about it, as indeed must be true of any concept, it becomes necessary to understand the circumstances under which, and the pressures in response to which, the concept was created and elaborated in any given milieu. This means that we must understand the political situation, social stresses and everyday assumptions of that milieu. And equally importantly, we must understand our own situation, in order to provide a check for ourselves; when might we be responding to our own contemporary pressures, rather than reflecting those of the past which is the object of our study?

Although as Almond states (p. 139), "In the Western imagination, Buddhism is the most recent of the major world religions, its construction and interpretation reaching back a mere century and a half," some images of Buddhism did exist in the West before Victorian times, and Almond himself and others have studied this history of encounter elsewhere. ${ }^{5}$ In addition of course we also have available some studies on the modern, mostly post-Victorian, shaping of Western thought about Buddhism and some of its principal aspects. ${ }^{6}$ The creation of Buddhism in the Victorian world, a process through which Westerners (a concept perhaps a bit more problematic than Almond seems to admit) classified diverse phenomena together within a discourse about "Buddhism," is divided by Almond into two periods: The first is that in which Buddhism is "out there," geographically, culturally and imaginatively other, but in the present and encounterable. The second is a later period, more or less after 1860, in which Buddhism becomes an object locatable in the past, in texts and manuscripts, but in the West, in libraries and oriental institutes. There is a move here from encountering living Buddhism in a foreign land in the present, an encounter which by definition must be to some extent 
mutual, to appropriating an ancient Buddhism created out of texts, texts which can be read but which cannot speak back, cannot contest interpretations, cannot assert anything but must bow to control and exploitation.

The key which separates the two periods of Victorian encounter and note that "encounter" certainly implies some object other than that created in the West - is the distinction between "there - now" and "here - then." We may say that the second period is characterized by a "textualization' of Buddhism, its virtual capture and confinement in books and libraries. This is a crucial element in the Western appropriation of the foreign object "Buddhism." As Almond puts it (p. 24), "Through the West's progressive possession of the texts of Buddhism, it becomes, so to say, materially owned by the West; and by virtue of this ownership, ideologically controlled by it."7 The move from the first chronological period delimited by Almond to the second is portrayed (p. 37) as illustrating a progressive bias toward domination and objectification. The first period is one in which "the beginnings of Western discourse about Buddhism did not hint of Buddhism as a decaying, degenerate religion. In the absence of an ideal textual Buddhism with which to compare what was encountered in the East, it could not. In contrast, those who saw Buddhism in the East in the second half of the century could not but measure it against what it was textually said to be, could not but find it wanting and express this in the language of decay, degeneration, and decadence." The creation of an ideal Buddhism out of textual materials allows those who control the resources, the texts, to do the creating, since only they can read the texts, and this allows them the freedom to prosecute their own agendas with the authority of "science." Those scholars who position themselves as interpreters of the past define this task (no doubt unconsciously) likewise as one of presenting and defending pristine orthodoxy, but an orthodoxy which they themselves define.

The identification of the locus of true, authoritative Buddhism as resting in the texts which lie in European libraries axiomatically produces a shift in the locus of power. As Almond says (p. 33): "Buddhism developed as a 'something' primarily said in the West, delimited and designated by virtue of its ideological containment within the intellectual, political and religious institutions of the West. 
Buddhism as it manifested itself in the East could only there be seen through the medium of what was definitively said about it elsewhere." It is therefore through this control over Buddhism's past that the West put itself in the position of judging Buddhism in the present deciding whether or not the contemporary faith of the people over whom, in many cases, it held colonial control met the standards set in their own past, but a past interpreted for them by their colonial masters. ${ }^{8}$ This allowed Westerners to (p. 37) "combine a positive evaluation of a Buddhism textually located in the West with a negative evaluation of its Eastern instances," in other words to, at a stroke, appreciate the virtues of Oriental creations, and honor them, while simultaneously escaping the necessity of acknowledging that contemporary Asians were heirs to this tradition and likewise worthy of respect. ${ }^{9}$

If all of this sounds familiar, it should. For Almond has, virtually lock, stock and barrel, adopted the theoretical framework of Edward Said's Orientalism. ${ }^{10}$ For Said (p. 3), Orientalism is "the enormously systematic discipline by which European culture was able to manage - and even produce - the Orient politically, sociologically, militarily, ideologically, scientifically, and imaginatively, during the postEnlightenment period." Moreover (p. 5), "The relationship between Occident and Orient is a relationship of power, of domination, of varying degrees of a complex hegemony ...." A few more phrases from Said's book should clarify Almond's debt to it. "Orientalism," Said wrote (p. 22), "responded more to the culture that produced it than to its putative object, which was also produced by the West." And related to (though not identical with) Almond's idea which, above, I termed "textualization," Said wrote (p. 52): "[T] he Orient studied was a textual universe by and large; the impact of the Orient was made through books and manuscripts, not, as in the impress of Greece on the Renaissance, through mimetic artifacts like sculpture and pottery." It is surprising that, except for a rather brief treatment (p. 5), Almond seems not to fully acknowledge his theoretical debt to Said. For future reference, it should be kept in mind that the discussion generated over the years by Said's book might be consulted with profit when Almond's theoretical analyses are at issue.

I mentioned above Almond's claim that in principle it was his 
intention not to evaluate whether or not a given position adopted or criticized by Victorian writers has been repudiated or accepted by further Buddhist researches. He has of course been forced into just such evaluations since, to over-simplify, without this distinction between what we hold to be fact or at least plausible and what we reject as ideologically conditoned by prejudices, we become unable to separate the historically plausible from the implausible. Without such a starting point, we will be unable to locate Victorian prejudice and separate it from "objective" reporting. It is necessary not only to examine ideological motivations but also the objective bases for what is being described. As an example we may refer to a case in which Almond may have overlooked the fact that one may be right for wrong reasons. That is, although he may well have correctly identified the ideological motivations of the author in question, this alone is not enough to reject that author's claim. In his discussion (p. 45) of the Victorian idea that the Oriental imagination is excessive, Almond refers without comment to $\mathrm{Ph}$. Colinet's remarks that no Hindu would have imagined that the Buddha could have been conceived except to the accompaniment of signs and marvels. Whatever Colinet's motivation for saying this, and whatever such an evaluation meant to him or others about the "oriental mind" and its excesses, I think that at least for those Indians (or "Hindus") who accepted the divinity of the Buddha - a group which no doubt included and probably still includes many whom we would consider to be devotees of faiths other than Buddhism - this is a fundamentally correct appreciation or characterization of a pre-modern, and still to a large extent contemporary, Indian world-view. Almond may well be right in implying that Colinet's statement was motivated by the general view that "the oriental mind" is one of childlike ignorance and indolence. But, it is a dangerous countermeasure to the prejudice that non-Western or premodern peoples are children or savages to suggest that they somehow share with the modern West a fundamentally similar view of the world or conception of reality. This latter idea says much about the ideological agendas of our own day which have difficulty in recognizing the difference between equality in value and equality in substance.

If we hesitate to draw distinctions called for by the evidence we uncover we make as big an error as if we inject our own ideological 
agendas into that evidence and draw conclusions not justified by the evidence itself. If in evaluating the researches of our predecessors we give too much weight to their ideological motivations, we will end up throwing out many babies with the bathwater. In some cases, it may be better to keep the babies, and just change the water. It is certainly necessary to ground our theories, hypotheses and ideas on assumptions with which we agree. And if we find fault with the assumptions, and thus the very basis of the reasoning, of our predecessors, we must certainly re-evaluate their conclusions. At the same time, having replaced old and unacceptable assumptions with our own, the subsequent reasoning and derived conclusions may still end up resembling those originally called into question by our re-evaluation. This may seem then like a waste of time. But in each case, until we actually go through the process, we will not know which conclusions we can keep and which must be rejected.

One of the central foci of any thinking about Buddhism is certainly the Buddha himself, and thus a natural question to begin with is, Who was the Buddha? It is here that, naturally, many of the ideas central to the Victorian conception of Buddhism come together, and it is here in his discussion of the Buddha that Almond's investigations mark some of their greatest advances over the works of others who have covered more or less the same ground. For 19th century people, Almond holds:

The Buddha of mid and late Victorian times is locatable in history through his contemporary textual presence. He is an object conceptually related to a developing naturalistic view of the universe, to an emergent critical view of the Bible, to an India under British hegemony, to a world view increasingly determined by a geologically and biologically based chronology and progressively less by a Biblical chronology and cosmology. The Buddha is very much a human figure; one to be compared not with the gods, but with other historical personalities - with Jesus, Mohammed, or Luther.

In contrast to this very human image, the Buddha of pre-Victorian times was located, primarily, not in history but in a realm beyond - a realm populated by the gods of India, of Greece, and of Egypt. Sometimes, he was more mundanely located; but even then it was in a place and time the parameters of which were determined by interpretations of biblical cosmology and biblical chronology. (p. 56)

The Victorian Buddha described here exists in texts, not through observation of who or what the Buddha may have been to living Buddhists in Asia. Whether he is god or man, he is "processed" 
according to European categories and interpreted according to European agendas. It is interesting to realize that it is only in the last few years that things are starting to change a little bit in Buddhist Studies in this regard, with increased attention being given to anthropological studies of Buddhist cultures, and new attempts to look at old evidence from the ancient past. ${ }^{11}$ Probably these new ways of looking at things have not yet filtered much into the common wisdom, either of Buddhist scholars or of students of Buddhism at large.

Looking backwards, the earliest attempts to locate the Buddha mythologically were based in large part on etymological analyses. This type of analysis has its background in early modern ideas about the Bible and history, and most especially the connection of language with this history. The legend of the Tower of Babel was taken very seriously, and early attempts to place Asian languages within such a Biblical framework determined much of the early discourse about the history of Asia, Asian culture and social institutions, and the relation between the latter and those of Europe. This is a history which Almond does not explore, ${ }^{12}$ preferring to concentrate upon the details of etymological and mythological identifications of the Buddha with, most notably, the Nordic Woden. These etymological and mythological fantasies make amusing reading today, and it is easy to forget how seriously this type of research was taken. Indeed, with only a touch of modern day chauvinism we can call such early efforts "proto-scientific," for they were the precursors of modern comparative philology. But at the same time we should not forget that, as great as some of the proponents of such comparative excesses were, they did not go uncriticised even by their contemporaries. A very humourous essay published in Dublin in 1870 "proves," using the methods of comparative mythology and etymology, that the famous F. Max Müller, editor of the Rgveda and of the series "Sacred Books of the East," one of the fathers of modern Comparative Religion and Buddhist Studies, and not at all coincidentally a strong and influential advocate of the "comparative" approach, was not a true human being but rather a personification of the sun. The argument is most convincing! ${ }^{13}$ That such a sarcastic and tongue-in-cheek critique of the comparative method was far from irrelevant or anachronistic one has only to observe that a few years after the publication of this article Emile 
Senart was to publish his Essai sur la légende du Buddha, ${ }^{14}$ in which he attempted to prove that the Buddha was in fact a solar deity. And Senart was by no means the only scholar to hold such a position. ${ }^{15}$

In the evolution of ideas about the Buddha himself, once again the dividing line falls around $1860 .{ }^{16}$ Before this time the Buddha was a divine being located in mythical time; afterwards he became a historical figure and an object of "objective" history. In this context Almond discusses (p. 67ff) the influence of European studies of the life of Jesus on contemporary studies of the life of the Buddha. It is usual to repeat the fairly obvious assertions of a connection between the European awareness of the fragile historicity of their own God and that of an alien savior, but Almond shows clearly and concisely who said what, and what their motivations were for saying so. It is one of the strengths of this book that Almond rarely stops short of suggesting what motivations may have led to a given position, and it is out of this search for motivations that Almond's outline of ideological pressures grows.

One importance of the Buddha for the Victorian polemicist, Almond points out, was the use to which he could be put in the project to create - out there - the ideal Victorian gentleman, this figure being dressed in the clothes of the polemicist's own choice. Having created one's ideal model, one "discovers" it and its existence proves the correctness of one's own position. This is a view in miniature of the whole ideological imaginative creation of Buddhism itself. Within a British colonial context it was mainly as a counter to the predominant Hindu system in India that the Buddha could be of use. The Buddha thus created was an opponent of caste, and of the priestly system which supported it, an advocate of social reform. This social reform, then, is the project of the polemicist who creates this Buddha, a Buddha who in fact becomes a Martin Luther of India; the latter point supports of course a strong anti-Catholic polemic at home in Europe. But then something odd happens: the Buddha is no longer a social reformer. This "was, in effect, the result of an attempt to protect the Victorian Buddha from being perceived as an early proponent of those forms of socialism that were perceived by many as threatening the structure of English society from the beginning of the 1880 s especially." (p. 75) The transformation which has taken place is 
as follows (p. 76): "in a context of anti-Catholicism, a radical social reformer rejecting the pretensions of a priestly ruling class could be embraced. But in a context of anti-Socialism, a radical social reformer rejecting the pretentions of the secular ruling class was unacceptable. The Buddha, too culturally powerful to be simply ignored, was moved to the right wing of the political spectrum." The polemicist, when the dynamic of his own polemic shifts, gives the Buddha a new set of clothes better suited to the times.

The Buddha, a symbol created by Europeans, is of course therefore a symbol manipulated by Europeans. But this last statement may also mean that at certain times our own contemporary views of the Buddha will correspond more closely to former views that they do at other times, depending in part on the degree to which our ideology agrees with that of former times. Especially if we accept the idea that the historical Buddha Sākyamuni, a man who lived in India in perhaps the fifth century before the Common Era, is essentially historically unknowable - because, most importantly, we have no certain evidence even that such a man lived - then there is no actual "fact" or set of "facts" to which any picture of the Buddha might correspond. There have been many attempts to write de-mythologized lives of Jesus, but the entire enterprise has been rightly criticized as logically confused. Similar attempts have been made to discover a historical Buddha, ${ }^{17}$ and these share the same problems. So our Buddha, anyone's Buddha (Buddhists included), can only be a Buddha of some portion of the multifarious Buddhist tradition, or a Buddha of our own making. Again, if we consider "the Buddha", as religiously we must, not as a historical man but as an enlightened being, logically the access to such a one is not through history. Any adjudication of the picture of such a being must come from elsewhere. But even if we aim at understanding how the enlightened Buddha was understood by others, I suggested above that it is necessary to posit an essentialist basis without which we cannot evaluate any argument. There are better and worse descriptions of an object because, however ultimately unknowable in its essence, there is an object which by its presence restricts what can be said about it. No matter how unknowable the Buddha, some statements are more plausible than others. Be this as it may, and even if one does not accept this reasoning, as Almond 
clearly sees it is still very possible to identify, and learn from, the ideological pressures which motivated people to develop certain ideas, whether or not we agree with those ideas. Even if we cannot know the "truth" of a situation, we can still identify factors which led others to hold certain positions. To some extent we can explore the ideology of Victorian interpreters of the Buddha, without ourselves being necessarily quantitatively any more objective than they.

The manipulation of the Buddha is a captivating case in point. Whatever the historical Buddha's social philosophy actually was, or whatever, rather, we today believe it to have possibly been, it is still possible to trace with Almond's help some of the ways in which scholars and polemicists of former times imputed one position or another to the venerable figure, with the motivation, Almond has shown, of promoting their own positions through the Buddha's charismatic authority. With this in mind we can both analyze and re-evaluate the traditional understandings we have received, and look at the picture contemporary works paint of the Buddha, for example, to see how far we can trace the concerns of contemporary social agendas within that picture. This may not directly help us to gain access to a remote and perhaps unreachable past, but it can clarify for us why we believe what we believe, and thus allow us to re-affirm or reject those beliefs.

The interaction between contemporary social, political and religious agendas and scholarly or popular dogmas is certainly not limited to the discourse of the Victorian period. For example, one of the commonly repeated notions about Buddhism in the present day is the idea that the Mahāyāna is a lay-oriented movement. Without going into detail, and setting aside the question of the "true state of affairs" which may or may not be knowable, I think we can hypothesize that there are two basic causes which have led to this opinion being widely held today. The first is that it is standard doctrine among Japanese Buddhist scholars and Buddhist lay believers, and the second is that in the West it was the theory espoused by among others (like Edward Conze - for whom the Mahāyāna was the "new dispensation" - and D. T. Suzuki) one of the most influential modern Buddhist scholars in Europe, Étienne Lamotte. To over-simplify matters, in the first case it is standard doctrine of several of the most important Japanese 
Buddhist sects, such as the Pure Land Schools and those connected with the Lotus Sūtra (Nichiren-shū, the Reiyukai, and so on), that the Mahāyana is a preaching for the laity, as opposed to the old, "Hinayāna" teaching which is for renunciant monks and nuns. This dogma has become, not necessarily with any conscious reflection, transformed into and presented as historical fact not only by the religious leaders of these sects, but by scholars who belong to these sects (which means most Japanese Buddhist scholars). ${ }^{18}$ On the other hand, while no doubt Lamotte was to some extent influenced by these Japanese ideas, as he was by much Japanese Buddhist scholarship (despite few references to such in his notes), these are not his only influences. As Hubert Durt has recently pointed out:

There has been a tendency in the study of Mahāyaña to see the Bodhisattva ideal as a concession made by the community of Buddhist monks to the aspirations of the laity. This interpretation resulted from several dubious associations: Mahäyāna has sometimes been viewed as a movement similar to the Protestant Reformation in Europe. Moreover, some authors have been influenced by the typically Latin and Roman Catholic opposition between the clerical and the secular world, the secular world being divided later into responsible religious laymen (the French "laïcat") and anti-religious or anti-clerical laymen (the French "laïcaté," "laïcisme")."19

Durt refers to Lamotte in mentioning those authors who were so influenced. ${ }^{20}$ Of course, there is reference in even relatively early Mahāyāna Buddhist literature to the "householder bodhisattva." But both the exact meaning of such passages and the extent to which they reflect some historical situation must ultimately be evaluated with a sensitivity to an ancient Indian situation, avoiding as much as possible - by being aware of them - prejudices motivated by the ideological inheritance of the contemporary researcher.

I mentioned above the idea that the quest for political control was one important factor motivating certain interpretations of Buddhism. But the utilization of Buddhism in the Victorian world to support or challenge a given dogma extended beyond the realm of colonial or political policy. In connection with the question of whether mankind owes its existence to a natural process of evolution or to divine creation, one of the most hotly debated issues of the day and an issue in some quarters not yet put to rest, Almond observes that (p. 86 ) "the period during which there occurred the most vehement 
attacks on the evolutionary account of man correspond with that of the most savage criticism of the Buddhist doctrine of rebirth." But in the end, although the importance of the doctrine of rebirth for the Buddhist philosophical system was realized, it seems that generally people of the Victorian period were unable to make much sense out of it. This did not stop some from making use of the idea, for example to support their positions on the doctrine of evolution. But even if rebirth was recognized as central to the Buddhist doctrinal vision (for without it the doctrine of karma is incoherent), Buddhist cosmology was not. No necessary connection was postulated between the truth of the Buddhist cosmology and the religious truth of Buddhism as a whole, "prompted no doubt from the developing awareness that the value of the Christian tradition was not dependent on the truth of its cosmology." (p. 93) Since the Bible's cosmology was increasingly coming to be rejected and replaced with modern scientific thinking, it would have been incautious to insist that Buddhist cosmological ideas must guarantee the truth of the whole Buddhist system. If the Bible's cosmology was disconnected from the truth of its fundamental message, so could be that of the Buddhists. It is the presentation of observations such as this and of the evidence supporting such connections that allows a clearer picture of Victorian ideology to emerge through Almond's midwifery.

The spirit of the Victorian age can also be seen in the wider quest for origins (à la Darwin), a quest which Almond (p. 95) credits with the high value placed on the study of Pāli Buddhism, in contrast to Sanskrit (and presumably also East Asian) Buddhism. "Underlying the historical quest for origins was the assumption that the original was the essential." This assumption of an equation: original $=$ essential $=$ true is still with us to a rather large extent, and has contributed to a view that "non-original" Buddhism was necessarily corrupt and false.

According to Almond (p. $96 \mathrm{ff}$ ), the belief in Europe that Buddhism is essentially theistic was at first connected with a belief in the chronological priority of the Mahāyāna. But after the mid 1870s, when it became generally accepted that Pāli Buddhism was older than Mahãyāna Buddhism, claims that Buddhism was originally theistic disappeared. For those who were themselves not theists, the existence of Buddhism and its moral system, a system which was generally even 
if sometimes reluctantly approved of in the West, allowed them to argue then that theism was not a necessary condition upon which to ground morality. The response to this move in the polemical contest was for the defenders of theism to argue that, after all, Buddhist morality was essentially a selfish morality; true selfless morality must be grounded in God. Almond (p. 116-7) sees in this more than an attempt to defend the citadels of Christianity. "[T]he criticism of Buddhist ethics as selfish ... more crucially, I think, ... was determined by the cultural hegemony of the West over the East. This necessitated the view that, however ideal in precept Buddhist ethics might be, in practice it could not but be unconducive to the maintenance of society." He goes on:

The polarity of assimilation and rejection of Buddhist ethics among Victorian writers is therefore suggestive of the desire of the West ideologically to suppress the autonomy of the East, and thus to control it. Buddhist ethical precepts could be and were assimilated. But the idea that Buddhist societies failed to put them into practice made possible the rejection of the cultural viability of these societies, and validated the cultural hegemony of the West.

This formulation implies the idea that the colonial authorities responsible for the "maintenance of society" in Buddhist lands somehow manipulated - perhaps consciously - this view of Buddhist ethics as a tool of administrative control and hegemonic authority, even perhaps that there was some sort of conspiracy to promote a certain view of Buddhist ethics for political or even military purposes. I doubt very much whether such a position can be maintained in its extreme form, and also have reservations about the appeal to subconscious motivations of Victorian writers on Buddhism. To be sure, many writers were indeed connected with various colonial services, a connection which continued until quite recently with the École Française d'Extrême-Orient in Indo-China. The connection between the political goals of these colonial authorities and their Oriental studies and scholarly conclusions must, however, be traced in more detail before any conclusions should be drawn. Although Almond's researches are certainly an excellent beginning, without individual biographies of many figures, it will be impossible to really know what motivated any given position, even if general trends can be identified.

In addition to the utilization of Buddhist theism or non-theism in 
the moral realm, another tension developed by Victorian polemicists was that between two ideological schemes. First we have the following: pure, original Pāli Buddhism, and decadent, corrupt Mahāyāna, versus: repressively scholastic early Buddhism, and a later stage (Mahāyāna) at which the natural instincts to worship a deity could emerge. That is to say, once it was determined that Pāli Buddhism was non-theistic and Mahāyāna theistic, there were two ways of thinking about the evolution of the idea of theism. One was to see the earlier stage (represented by Päli Buddhism) as pure and original - and rational. A second was to view Pāli Buddhism as an early rationalistic stage during which logic was employed to suppress the natural human quest to recognize the deity. The corollary to this set of views of Pāli Buddhism is the alternation between one view of Mahāyãna as later and degenerate, and another view of it as a stage of release from the scholastic suppression of faith in which worship is acknowledged as true religion. Even during Victorian times, to uphold some aspects of any of these positions required a selective blindness concerning certain ideas which were accepted as historical fact. It is therefore of considerable interest to notice a recent book by Peter Masefield in which it is argued that "Buddhism, or at least Pali Buddhism, far from degenerating from a noble and humanistic path of self-improvement into a religion distinguished by faith in a higher power, grace and revelation ... has in fact suffered the reverse fate: it has degenerated into a humanistic path of self-improvement." 12 This latter opinion probably has little to do with debates over Buddhism and Christian theism or the relative value of Pāli and Mahāyāna Buddhism, but it seems unlikely that even today discussions over the status of revelation and divinity in Pāli Buddhism have escaped being influenced by the forces at work in Victorian times.

If some of the debates over aspects of Buddhist religiosity or institutions were motivated by inter-religious or inter-sectarian conflicts in the West, others can be traced to altogether different causes. While it is true that some attacks on Buddhist monasticism were motivated by anti-Catholic feelings, more generally the attitude that monastic isolation is antithetical to the work ethic was apparently responsible for this position. It is of interest that Jesuits also leveled criticisms against Buddhist monasticism (in China) for its sloth. It 
seems that while Victorians could on the whole appreciate the active side of Buddhism, and especially its ethical system (with the reservations mentioned above), they rejected its contemplative side which they perceived as an instance of oriental laziness. This appears to be very much the opposite of the situation we have today, in an age in which Zen, Tibetan Buddhist meditation and Vipassanā are the areas of Buddhism in which Westerners seem to take by far the greatest interest. The history of this transformation and the motivations behind it are no doubt quite interesting, and perhaps revealing about modern attitudes and agendas in the same way that the Victorian critiques of monastic quietude inform us about Victorian thinking.

The polemical environment of the Victorian period which led authors to contrast Buddhism - indeed all other religions - with Christianity, to compare it favorably, to reject it as false, or to see in it a preparatory stage for the final truth - such an environment is a thing of the past. If anything, it has been replaced with an attitude, in some circles at least, more akin to that of the first Western converts to Eastern religions, an attitude which seeks a perfect answer to the problems which plague the society in which the convert happens to live. This reversed view is equally unbalanced, idealizing the mysterious East, but it responds in the same fashion as earlier prejudices to its own contemporary polemical context, and deserves to be examined critically.

In his conclusion (p. 140) Almond summarizes one of his most important points by stressing again the dominance of Europe over the Orient:

It was the Victorians who developed the discourse within which Buddhism was circumscribed, who deemed it a worthy focus of Western attention; it was they who brought forth the network of texts within which Buddhism was located. And it was they who determined the framework in which Buddhism was imaginatively constructed, not only for themselves, but also in the final analysis for the East itself.

The last phrase here is crucial: although Almond never alludes to the idea, Agehananda Bharati's concept of the "pizza effect" refers to precisely this phenomenon. ${ }^{22}$ Briefly put, this label refers to the process of the export of a certain cultural artifact from culture $A$ to culture $\mathrm{B}$. When the artifact comes to be valued in culture $\mathrm{B}$, the importer, those in the culture of origin come to value it too, and 
reimport it with renewed value, a value much higher than that they originally assigned to it. This is true of the history of pizza in Italy and of Buddhism in, for example, Sri Lanka. The latter case has been investigated along with many other aspects of the modernization of Buddhism in Sri Lanka by Richard Gombrich and Gananath Obeyesekere in their delightful and fascinating work Buddhism Transformed: Religious Change in Sri Lanka. ${ }^{23}$ In that work the influence of modern and Western ideas, which includes a renewed value placed on Pāli texts, is capsulized with the term "Protestant Buddhism." The same term has been taken up by Gregory Schopen recently in an attempt to illustrate how such modern ideas have deeply influenced contemporary views of ancient Buddhism as well. ${ }^{24}$

Almond's presentation is primarily that of materials, and he has gathered together a truly massive and impressive volume of evidence concerning the, mostly popular, view of Buddhism in Victorian England. The references presented in this book should provide a good basis for future work. The analysis which accompanies this tremendous amount of data is almost always interesting and often very stimulating and suggestive. The central point of the work, that, as Almond observes in the final sentence of the book, "The Victorian world in all its diversity, confident of its cultural hegemony, was incorporated, and crucially so, in its interpretation of Buddhism," is convincingly presented. The reader is persuaded that the West, in appropriating the literature and the culture of the East, in turn imaginatively created an East and a Buddhism through its reading of Eastern literature and culture, and moreover an East and a Buddhism which became real through the pressures of the cultural, political and military hegemony of the West over that East.

The whole process, however, was perhaps somewhat more nuanced than Almond's presentation makes it seem. In particular, some of the presuppositions of Almond himself seem to slant his coverage in directions which exaggerate certain extremes. But if in presenting his thesis in this exaggerated form Almond draws the reader's attention to the idea that ideological sensitivity is vital in any reading of the past, as it is also in the present, then this exaggeration has done good service. It is always helpful and necessary to ask why someone might have said something, or said it in a certain way, and if an answer can 
only or best be painted in broad, exaggerated strokes, then a more refined appreciation can be left for a later time when the task of problematizing the issue in the first place has already been accomplished. Future discussions of "orientalism" will, thanks to Almond's book, have to deal with Buddhism and its place in the discourse of the West. Those future discussions may sometimes produce more nuanced evaluations than Almond, as a pioneer, has been able to provide.

Aside from the many issues he does discuss, there are other questions which Almond does not take up but which would be interesting to explore. What kind of awareness of Buddhism, for example, was there among those who did not go out of their way to think about it or write about it? What, in the Victorian and postVictorian worlds, is the broader relation between thinking about Buddhism and Hinduism, and "Orientalism" more broadly understood? It will be interesting to look into these questions in the future. But even now, with the materials put at our disposal by Almond it should be possible, as I have suggested above, for us as modern people interested in Buddhism, whether scholars or not, to examine some of our inherited presuppositions, and through this process, it is to be hoped, arrive at a more satisfactory basis upon which to rest our imaginative reconstructions of the past and our further studies of that past. And with the awareness cultivated by Almond's analyses, we should be able to uncover motivations in the works of post-Victorian writers and scholars which have likewise shaped the way we see the Buddhism of today and that of the past. Almond's book is to be welcomed for the materials it presents, the critique it offers, and the challenge it lays down to all those who would like to think seriously about how to understand the Buddhist traditions.

I close these few comments on this fine work with the wish for an affordable paperback edition of the book which could be assignable for classroom use; the present hardback edition, after all a mere 186 pages, is priced, at $£ 25$ or $\$ 34.50$, so high that there is no way one could ask students to even consider its purchase. This trend toward exorbitant pricing should be combated at every opportunity. 
held in the English speaking world. Was this work particularly important in Victorian England? The arithmetic on page 49 is not clear, because Almond has omitted some vital information. Although Sangermano's book was published in 1833 , referring to a report of 1693 Almond says "a hundred years later, Father Sangermano. ..." Forty years would seem to be missing somewhere. In fact, according to the preface to the original edition of the book by (Cardinal) N. Weisman (see below) and the Lessico universale italiano di lingua lettere arti scienze et tecnica (Roma: Instituto della Enciclopedia Italiana, 1978: vol. 20: 4), Sangermano was a Barnabite missionary born in Arpino in 1758 who arrived in Rangoon in July, 1783, proceeding immediately to Ava but shortly thereafter returning to Rangoon. He arrived back in Italy in 1808 . His book was written partly in Ava and partly after his return, and he died in 1819. This book which, the preface states, contains translations made with the assistance of native scholars of "all that is worthy of notice in the three Kiam, the Vinì, Padimot and Sottan," seems not to have been utilized much by modern Buddhist scholars, although Burnouf (Le Lotus de la Bonne Loi [Paris, 1852: 446]) remarks that F. Buchanan knew and used it. The book will no doubt well repay further examination. On page 95 of Almond's book we find a completely unacknowledged very close paraphrase, virtually a quotation, from p. 77 of the first part of de Jong's article mentioned in note 6 of the present review. This should have been noted by Almond in a footnote. On page 140 we read the following: "In part, at least, this was an aspect of the Western creation of two qualitatively different modes of being human, the oriental and the occidental, the latter of which was essentially other, and which was in most instances perceived as inferior." Is not the order to be reversed? Surely it is the former which is "essentially other."

Finally a few corrections to the Bibliography are needed: The original publication of Alexander Cunningham's Bhilsa Topes is: Bombay: Smith, Taylor and Co. and London: Smith, Elder \& Co., 1854. The correct title of Robert Knox's book, and its publication information, are: An Historical Relation of the Island Ceylon, in the EastIndies, Together with an Account of the Detaining in Captivity the Author and divers other Englishmen now Living there and of the Author's Miraculous Escape. London: Richard Chiswell, 1681. The odd spelling used repeatedly by Almond, "Ceylone," is not attested in the American National Union Catalog or the British Museum General Catalogue, nor is it found in the facsimile reprint of the first edition, which is accompanied by a very informative introduction by H. A. I. Goonetileke: New Dehli: Navrang, 1984. Finally, the correct publication data for the book of "Sangermano" is: Vincentius Sangermano, A Description of the Burmese Empire, compiled chiefly from native documents by the Rev. Father Sangermano, and translated from his MS by

William Tandy. Rome: Oriental Translation Fund of Great Britain and Ireland, 1833. For the three preceding items Almond has listed only reprint editions, and although he states in the text the correct dates of publication, a look at only the bibliographic citations could suggest that these books are modern. Especially in studies such as the present one, concerned with intellectual history, correct bibliographic information is crucial, and should be supplied in all cases. If the author has utilized a reprint edition, this should of course be noted, but in addition to the original publication information. 


\section{NOTES}

* I want to thank Griff Foulk and Luis Gómez for their insightful and very useful comments on earlier drafts of this review.

1 Paris: Aubier, 1952.

2 P. J. Marshall, ed., Cambridge: Cambridge University Press, 1970. This book appeared under the series rubric "The European Understanding of India," but was apparently the only volume of that series to appear. No notation of series appears in the present volume, and neither the American National Union Catalog nor the British Museum General Catalogue list similar titles beginning with "The British Discovery of ...." Marshall's book is mentioned only very much in passing by Almond (p. 70).

3 It may not be pure chance that La Vallée Poussin used the word "espèces," given the influence of Darwinism on the discourse of the period, a topic discussed by Almond. In his discussion La Vallée Poussin seems to limit himself to the many species of Indian Buddhism. In the discussion preceding the phrase quoted above, La Vallee Poussin writes: "Buddhism, then, may be a collection of contemporary or consecutive religions, quite distinct in their foundation even though they may reside together in the same mind. . . But it is yet something else, since these multiple and diverse forms of Buddhism are not only joined by the usage of the same symbols and the same nomenclature, but more still they are bound, in spite of their difference, by a sort of historical progress." Louis de la Vallée Poussin, Bouddhisme: Opinions sur l'histoire de la dogmatique. Études sur l'Histoire des Religions 2. Paris: Gabriel Beauchesne \& C., 1909: 20-21. Almond does not refer to this study or any other work of the great Belgian scholar, whose earliest paper was published in 1891 .

${ }^{4}$ As an example of an attempt to get beyond old, commonly accepted but actually unproven, notions of Buddhist history, see Gregory Schopen, "Two Problems in the History of Indian Buddhism: The Layman/Monk Distinction and the Doctrines of the Transference of Merit," Studien zur Indologie und Iranistik 10 (1985): 9-47.

5 In addition to the work of De Lubac, mentioned above, we may note the following, some of which are not listed by Almond (the list could be much lengthened): By Almond himself we have "The Buddha of Christendom: Review of the Legend of Barlaam and Josaphat," Religious Studies 23/3 (Sept. 1987): 391-406, and the (I believe) still unpublished "Buddhism in the West: 300 B.C.-A.D. 400," to appear in The Journal of Religious History. [I know this paper only from Almond's reference.] An earlier related paper by Almond is "The Medieval West and Buddhism," The Eastern Buddhist 19/2 (1986): 85-101, but oddly absent is reference to Almond's own "The Buddha in the West: From Myth to History," Religion 16 (1986): 305-22, virtually a summary of the present book. Almond has not referred to two papers by David A. Scott: "Christian Responses to Buddhism in Pre-Medieval Times," Numen 32/1 (July 1985): 88-100, and "Medieval Christian Responses to Buddhism," The Journal of Religious History 15/2 (Dec. 1988): 165-84.

6 Perhaps the best introduction to Western academic studies of Buddhism is that published serially by J. W. de Jong, "A Brief History of Buddhist Studies in Europe and America," The Eastern Buddhist 7/1 (1974): 55-106; 7/2 (1974): 49-82; "Recent Buddhist Studies in Europe and America: 1973-1983," The Eastern Buddhist 17/1 (1984): 79-107. (The first two have been reprinted in book form in India, and translated into Japanese and Chinese.) Despite the titles of these papers, de 
Jong actually deals almost exclusively with philological studies on Indian Buddhism, to the neglect of both Far Eastern Buddhism and religious and sociological studies. No comprehensive appreciation of such works exists, although occasionally surveys of, for example, recent work on Japanese Buddhism, appear. [De Jong recently published "Buddhist Studies 1984-1990" in Chüö Gakujutsu Kenkyüjo Kiyö 20 (1991): 1-60, but it is much less useful than his previous surveys.] Guy Richard Welbon discussed in detail Western attempts to come to grips with one of the central ideas of Buddhist doctrine in The Buddhist Nirvāna and its Western Interpreters. Chicago: The University of Chicago Press, 1968 . (See the critique by J. W. de Jong in the Journal of Indian Philosophy 1 [1972]: 396-403.) I have not yet been able to see the recent study of Andrew P. Tuck, Comparative Philosophy and the Philosophy of Scholarship: On the Western Interpretation of Nägärjuna. Oxford University Press, 1990. Regarding the introduction of Buddhism to North America, see for example Rick Fields's How the Swans Came to The Lake: A Narrative History of Buddhism in America, Boulder: Shambala, 1986, which is rather more documentary than analytical.

Comparatively less work has been done (at least in Western languages) on the history of modern Japanese reflection and research on Buddhism. Silvio Vita has published one short article on this subject, "Interpretations of Mahäyāna Buddhism in Meiji Japan: From Religious Polemics to Scholarly Debate," Transactions of the International Conference of Orientalists in Japan 31 (1986): 44-57, and he is currently preparing a detailed study of this and related topics. I also owe to his kindness a copy of the recent paper by Jackie Stone, "A Vast and Grave Task: Interwar Buddhist Studies as an Expression of Japan's Envisioned Global Role," in Culture and Identity: Japanese Intellectuals in the Interwar Years, J. Thomas Rimer, ed. Princeton: Princeton University Press, 1990: 217-33.

A question which I believe has not yet been dealt with is the degree of influence exercised by Japanese Buddhist thinking on European ideas about Buddhism. It seems clear, for example, that some of Max Müller's impressions about the Mahāyāna must have been formed to a considerable extent by his conversations with his students Nanjō Bunyū (Bunyiu Nanjio) and Kasawara Kenjū (Kenjiu Kasawara). The ideas he got from these two were passed through him to the Western scholarly world. Many perspectives of the traditional Japanese understanding of Buddhism reached the West, as it were, through this back-door. A study of these influences would be most welcome. I may add that I have lately received a copy of a paper presented at the 1991 American Academy of Religion conference by Robert Sharf, "Occidentalism and the Zen of Japanese Nationalism," in which he investigates the ways in which Western notions of Zen were shaped by the ideological agendas of pre-war Japanese thinkers, most notably D. T. Suzuki. I understand that Sharf's paper will be published in the future in a volume on Orientalism to be edited by Donald Lopez.

7 Although not mentioned by Almond, this process should be considered part of the greater movement referred to by Raymond Schwab as the "Renaissance Orientale" in his book of the same title. Hubert Durt has observed that "almost all the Buddhist converts in Western Europe have been influenced by books.... They remain thus in the intellectual tradition of the 'Renaissance Orientale." "The Growth of Buddhism in the West: Its Reality and Meaning." Buddhism and the Modern World. Seoul: Dongguk University, 1977: 87.

${ }^{8}$ It is a measure of Almond's concentration on the Indian sub-continent, with some 
attention to China, that Japan - which of course was never colonized - is little considered. Almond's general thesis is not necessarily inapplicable to the Japanese case, but a more refined treatment would be necessary. One would have to consider less blatant forms of ideological control and manipulation against the backdrop of Japan's opening to the West.

9 The case, however, should not be overstated. While it is true, as Almond (p. 25) points out, that Klaproth, Schmidt, Csoma de Körös and others "were seminal in establishing the Buddhism of Northern Asia as a textual object," it should not be forgotten that these scholars relied heavily on the living, learned traditions of Mongolian (Buriat) and Tibetan Buddhists. The contributions of these scholars were, to be sure, to an appreciation of the literature of Buddhism rather than to any sort of anthropological approach to its contemporary state. But it was an appreciation of the literature very much interpreted through a living and vital, albeit scholastic, tradition. This is in contrast to some later encounters with native traditions which suffered from the so-called pizza effect, on which see below.

10 New York: Vintage Books, 1979.

11 On the latter issue one may consult with great profit Gregory Schopen's "The Buddha as an Owner of Property and Permanent Resident in Medieval Indian Monasteries," Journal of Indian Philosophy 18 (1990): 181-217.

12 He does allude to it briefly in the context of chronology on p. 62.

13 Only the French translation is available to me: H. Gaidoz, "Comme quoi M. Max Müller n'a jamais existé: Étude de mythologie comparée," Mélusine: Recueil de Mythologie II (Paris, 1884-85): 73-88. The English original was published in 1870 by students of Trinity College, Dublin in Kottabos. A College Miscellany. The title of the original as given in the French is "Le mythe solaire d'Oxford, contribution à la mythologie comparée." The French translation has the advantage of helpful notes which explain the allusions and inside jokes with which the text is peppered.

14 Originally published in the Journal Asiatique in $1873-75$, then as a book: Paris: Imprimerie Nationale, 1875.

15 In this regard see the first part of de Jong's paper mentioned above in note 6, pp. $79 \mathrm{ff}$.

${ }_{16}$ Note that Said (p. 206) also pointed to almost the same period, in his case 1870 , as a crucial turning point.

17 A quite recent example is H. W. Schumann's The Historical Buddha (London: Arkana, 1989). Schumann's avowed goal (p. ix) is to exclude "all legends which developed around the person of the historical Buddha, except in so far as a historical kernel could be detected in them. The book deals with the demythologized person of the great sage." I would dispute the degree to which virtually any statement about "the great sage" in Schumann's book can be defended according to the generally accepted canons of historical evidence. Schumann's statements about what the Buddha thought and felt (!) will obviously be hard to disprove.

18 It seems likely that one motivation for this position is the fact that those who have been responsible for the framing of these doctrinal interpretations recognize that they themselves fit, if in any classical Buddhist category, in that of the lay bodhisattva, as they have not taken monastic precepts themselves. If this supposition is correct, one factor motivating the Japanese advocacy of lay Buddhism as a preaching authenticated by tradition is the transparent desire to justify their own historically conditioned faith. 
Of course this by no means invalidates their own religious innovation. But if we examine the situation historically, we may have to identify as innovation what these Japanese sectarians claim as their (Indian) inheritance.

19 "Bodhisattva and Layman in the Early Mahāyãna," Japanese Religions 16/3 (1991): 1-16. Page 4.

20 Although I believe he has never published this opinion, referring to it only in personal conversations, Prof. Durt has repeatedly mentioned that Lamotte's efforts to place emphasis on the lay-orientation of the Mahāyäna were related to his position vis-à-vis contemporary lay efforts to modernize the Roman Catholic church in Europe (we are talking here of the days before Vatican II), and free it from its priestly domination. Certainly this is an issue which deserves further study, especially given the great influence the ideas of Prof. Lamotte have had on modern Buddhist studies, an influence which is growing with the continued translation of his works into English. 21 Paul Harrison, "Buddhism: A Religion of Revelation After All?" Numen 34/2 (1987): 257, in a review article on Peter Masefield's Divine Revelation in Pali Buddhism. Colombo: The Sri Lanka Institute of Traditional Studies, and London: George Allen \& Unwin, 1986.

22 The locus classicus for this notion is found in Bharati's paper "The Hindu Renaissance and its Apologetic Patterns," Journal of Asian Studies 29/2 (1970): 267-87, especially page 273. I thank Gregory Schopen for the reference to this published expression of Bharati's idea.

23 Princeton: Princeton University Press, 1988. As far as I noticed, however, the authors do not refer to Bharati or the "pizza effect" by name, although many of the phenomena they describe could be accurately classified as instances of this phenomenon.

${ }_{24}$ See "Archaeology and Protestant Presuppositions in the Study of Indian Buddhism," History of Religions 31/1 (1991): 1-23. 